\title{
Design and Fabrication of Electrolyte-Supported Tubular SOFC Combined with Supercritical Water Oxidation on Biomass Gas
}

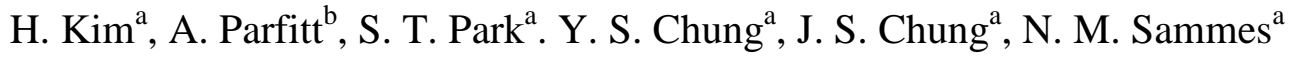 \\ ${ }^{a}$ Department of Chemical Engineering, Pohang University of Science and Technology, \\ San 31, Hyoja-dong, Nam-gu, Pohang, 790-784, Korea \\ ${ }^{\mathrm{b}}$ Institute for Residential Innovation, Shepherdstown, West Virginia 25443-0416, USA
}

\begin{abstract}
Solid oxide fuel cells (SOFCs) are relatively simple and environmental friendly devices for the production of electricity from hydrocarbons. The use of a high pressure supercritical water (SCW) reactor containing a SOFC has the potential for using a multitude of logistical liquid fuels that would otherwise not be possible in a regular SOFC system. A SOFC-SCW system was designed to allow the anode to be exposed to the pressure and chemical milieu of the supercritical water oxidation reactor. The effects of the amount of water/fuel and oxygen fed into the reactor under SCW conditions at $400^{\circ} \mathrm{C}$ were studied. The effects on electrochemical performance as well as preliminary results on a number of feed stocks, for example pectin, are also described.
\end{abstract}

\section{Introduction}

Solid oxide fuel cells (SOFC) have been widely developed because they show high conversion efficiency and do not require expensive precious metals due to operation at high temperatures (1-2). They can be fueled by internally reforming hydrocarbons, such as methane, propane and butane (3). SOFCs have two types of geometry (i.e. tubular and planar). Planar SOFC shows higher performance than that of tubular SOFC due to lower ohmic resistance, whereas the tubular SOFC has higher thermo-cycling stability than that of planar because of its geometry (4). Supercritical water oxidation (SCWO) has gained great attention because it can easily produce a product gas (i.e. hydrogen, carbon dioxide, carbon monoxide and methane) and store high pressure hydrogen due to the reaction medium of the SCW (At $\mathrm{T}>374^{\circ} \mathrm{C}$, liquid water at $22 \mathrm{MPa}$ ) which is converted to a homogeneous gas-like state; hydrogen bonds break down and water becomes a nonpolar solvent. The produced gas can be used as the fuel for SOFCs (5-6). The SCW-SOFCs combined in the SCWO and SOFC processes provide electrochemical oxidation of biomass, such as sewage solids or waste food. In particular, integration of SCWO and SOFCs gives an unique advantage of using the product fuel from the SCWO directly in the SOFC (7) without CO poisoning.

In this paper, the SCW-SOFC system is described in detail using an electrolytesupported SOFC which were fabricated using an optimized process. Further, we demonstrated that ionic-electronic conduction is maintained when the anode/electrolyte is exposed to the pressure and chemical milieu of the SCWO reactor. Moreover, the electrochemical performance behavior under different amounts of fuel feed was analyzed. 


\section{Fabrication of an Electrolyte-supported Tubular SOFC}

Figure 1 shows the electrolyte-supported SOFC fabrication process. YSZ $\left(\mathrm{Y}_{2} \mathrm{O}_{3}\right.$ doped $\mathrm{ZrO}_{2}, 0.3 \mu \mathrm{m}$, Tosoh, Japan) electrolyte powder was kneaded with the organic additive powders. The dough was extruded by a piston extruder, and pre-fired at $1100^{\circ} \mathrm{C}$ for 3 hours. NiO-ScSZ (nickel oxide, $0.8 \mu \mathrm{m}$, JT Baker, USA, and $10 \mathrm{~mol} \% \mathrm{Sc}_{2} \mathrm{O}_{3^{-}}$ doped $\mathrm{ZrO}_{2}$, Anan Chem. Co., Japan) anode functional layer was then dip coated onto the tube, and sintered at $1400^{\circ} \mathrm{C}$ for 5 hours. LSCF-GDC $\left(\left(\mathrm{La}_{0.60} \mathrm{Sr}_{0.40}\right)_{0.995} \mathrm{Co}_{0.20} \mathrm{Fe}_{0.80} \mathrm{O}_{3-\mathrm{x}}\right.$ $\left(\mathrm{Ce}_{0.90} \mathrm{Gd}_{0.10}\right) \mathrm{O}_{1.95}$, Fuelcellmaterials, USA) and LSCF $\left(\left(\mathrm{La}_{0.60} \mathrm{Sr}_{0.40}\right)_{0.99} \mathrm{Co}_{0.20} \mathrm{Fe}_{0.80} \mathrm{O}_{3-\mathrm{x}}, \geq\right.$ $1.1 \mu \mathrm{m}$ Fuelcellmaterials, USA) were coated and fired at $1150^{\circ} \mathrm{C}$ for 3 hours. The unit cell was reduced at $700^{\circ} \mathrm{C}$ for 1 hour in a reducing atmosphere (8).

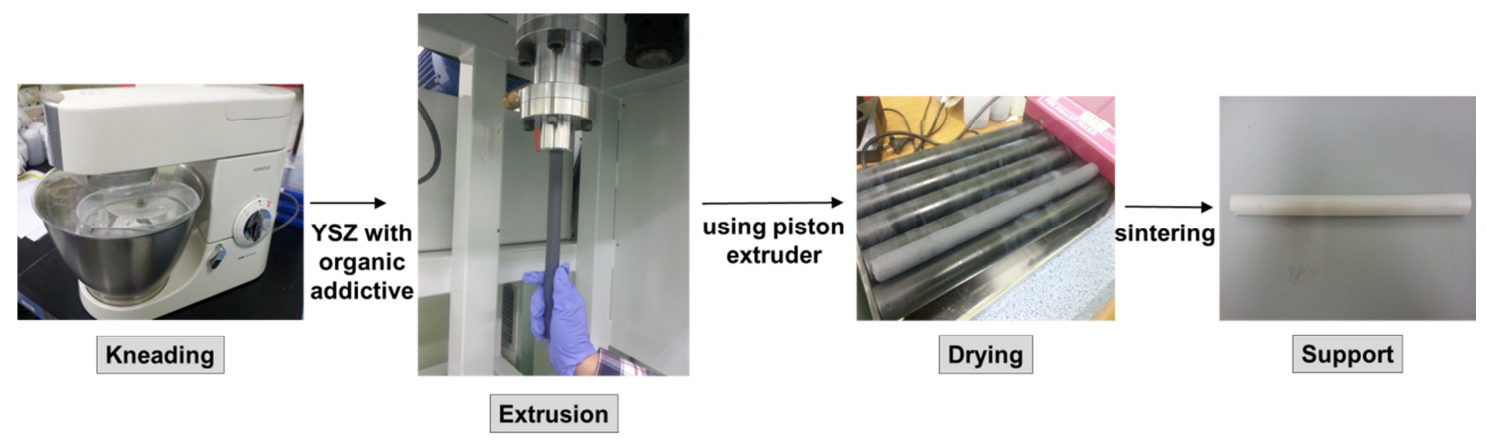

Figure 1. Electrolyte-supported tubular SOFC production process.

The unit cell was characterized by a scanning electron microscope (SEM, SEC SNE$4000 \mathrm{M})$ to observe the microstructure and evaluate its characteristics. The electrolyte must be stable in redox environments, and it should form a dense layer to prevent gas transport (9). Figure 2 shows the SEM images of the surface and cross-section of the electrolyte-support sintered at $1400^{\circ} \mathrm{C}$. The electrolyte support of YSZ formed a dense structure with thickness of $1.5 \mathrm{~mm}$. Note that the support contains no open pores on the surface and no connected pores across the dense layer.
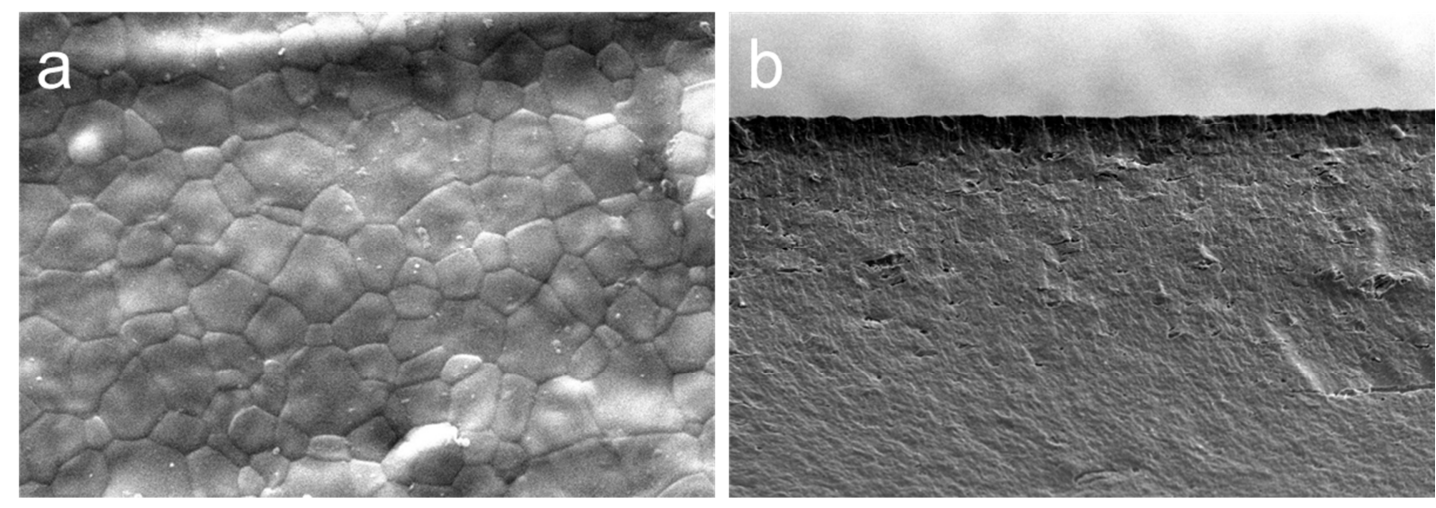

Figure 2. SEM images of electrolyte-support sintered at $1400^{\circ} \mathrm{C}$; (a) surface, (b) crosssection.

Figure 3a shows the electrolyte-supported tubular SOFC of $15 \mathrm{~mm}$ diameter that was fabricated in this study; the anode area was $7.1 \mathrm{~cm}^{2}$. Figure $3 \mathrm{~b}$ shows the cross-section SEM images of the electrolyte-supported tubular SOFC. The thicknesses of the anode and cathode are respectively 10 and $15 \mu \mathrm{m}$. 

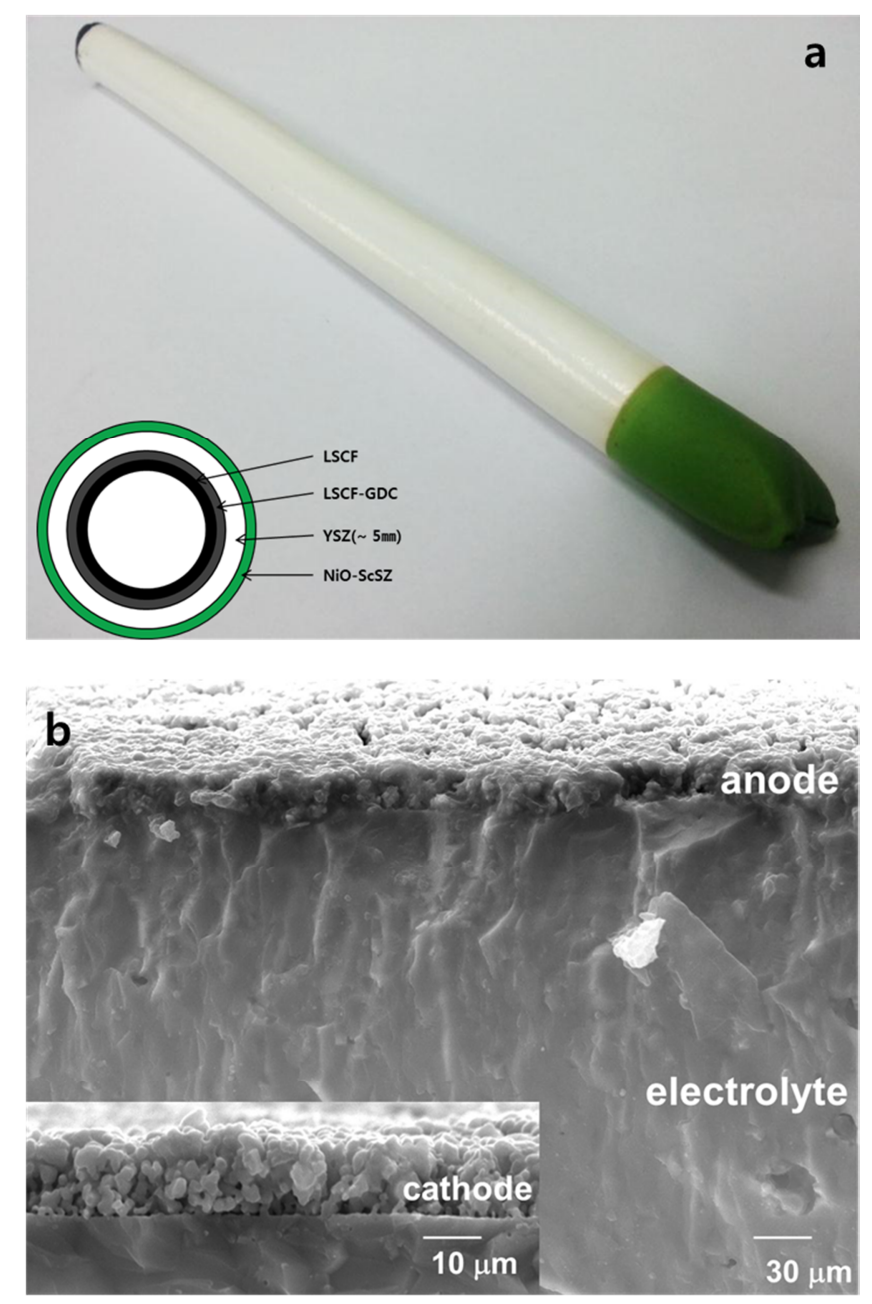

Figure 3. (a) Electrolyte-supported tubular SOFC fabricated in this study; (b) SEM images of cross-section of electrolyte-supported tubular SOFC.

\section{Designing the SCW-SOFCs System}

Figure 4 depicts a schematic cross section of the SCW-SOFCs system. SOFCs must be divided into two parts, the anode and cathode, due to the different electrochemical reactions. SCW-SOFCs consisted of a batch reactor with a heating system in which the SOFC is placed inside the reactor with the anode on the outside of the tube, and air passed down the inside of the tube. Since the anode current collection is difficult to obtain due to its location in the SCW chamber, the anode current collector is electrochemically connected to the batch reactor. An important issue for operating the cell is whether it can withstand the SCW's high pressure and high temperature conditions. Therefore, a thick electrolyte support was used in this study. In order to seal between the cell and the reactor, a metal O-ring was used and a rubber O-ring used as a sealant for the $\mathrm{SCW}-\mathrm{SOFC}$ system at high pressure and temperature. Since the rubber composite is especially unstable above $220^{\circ} \mathrm{C}$, certain parts close to the rubber O-ring require cooling for protection by the batch water circulator. Additionally, the system was equipped with 
a back pressure regulator for reducing the pressure when pressure exceeded above the set point.

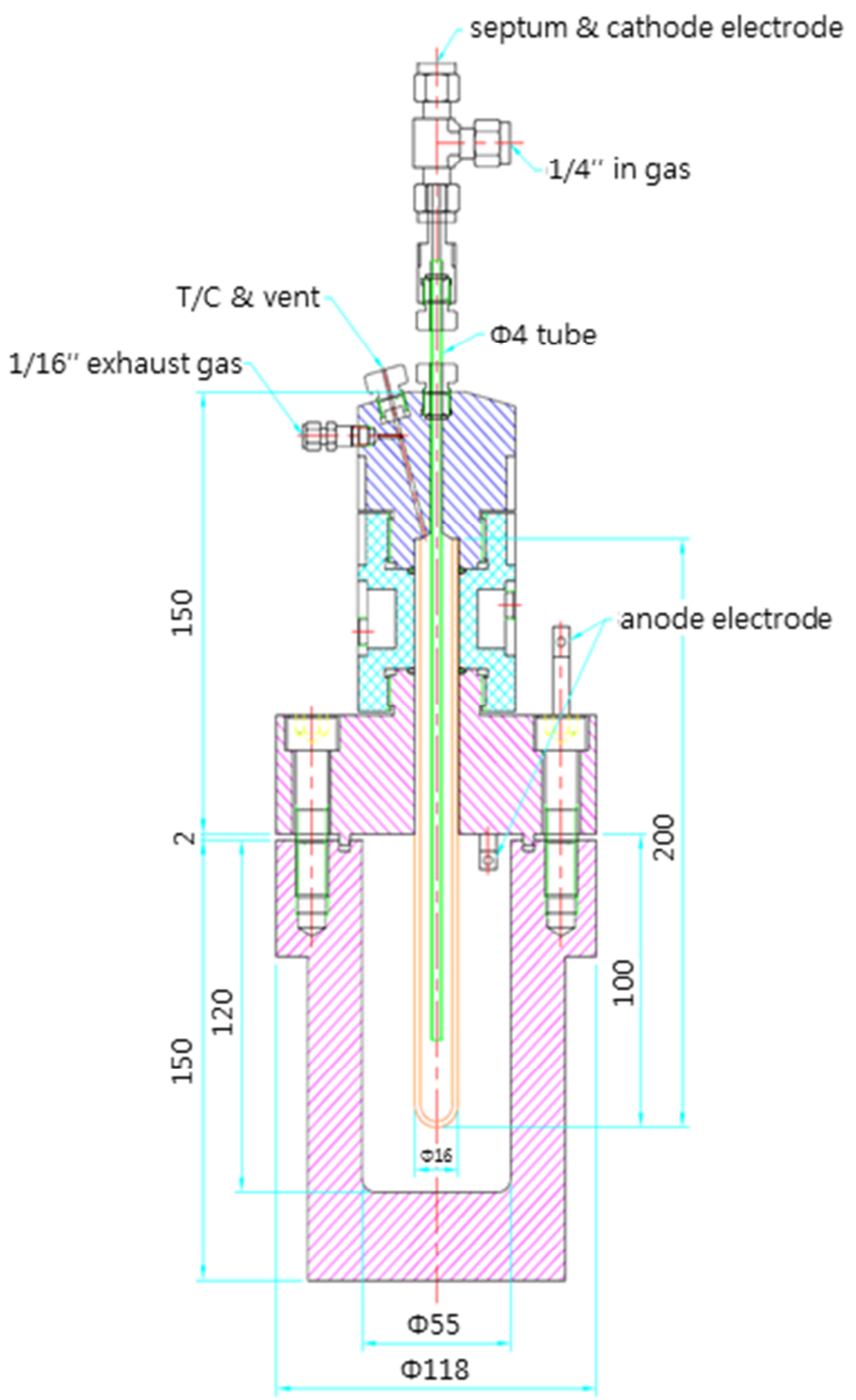

Figure 4. Schematic diagram of SCW-SOFCs.

\section{Assembly of the SCW-SOFCs System and Its Performance}

Figure 5 shows the assembly process for the SCW-SOFC system. For the assessment of electrical characteristics of the unit cell, the anode current was collected by wrapping $\mathrm{Ni}$-felt on anode and winding $\mathrm{Ni}$-wires around it in the circumferential direction. Then, LSCo $\left(\left(\mathrm{La}_{0.80} \mathrm{Sr}_{0.20}\right)_{0.95} \mathrm{CoO}_{3-\mathrm{x}}, \geq 1.0 \mu \mathrm{m}\right.$, Fuelcellmaterials, USA) paste was evenly applied to the anode surface to reduce contact resistance. Further, Ag meshes connected with Ag wires were closely attached onto the inner surfaces of the anode using LSCo paste. Prior to assembling the SCW-SOFCs system, 5 and $10 \mathrm{wt} . \%$ of pectin $\left(\mathrm{C}_{6} \mathrm{H}_{10} \mathrm{O}_{7}\right)$ dissolved in water were fed into the chamber. The parts were then assembled following Figure 5. 
Tests were conducted in an electric furnace to measure the unit cell performance characteristics of the electrolyte-supported SOFCs. The temperature was ramped up at $1.67^{\circ} \mathrm{C} / \mathrm{min}$ to $400^{\circ} \mathrm{C}$ for performance evaluation. Air was injected as an oxidizing agent. A DC electronic load (Daegil Electrics DP-500) was used to measure open circuit voltage (OCV) during heating up.

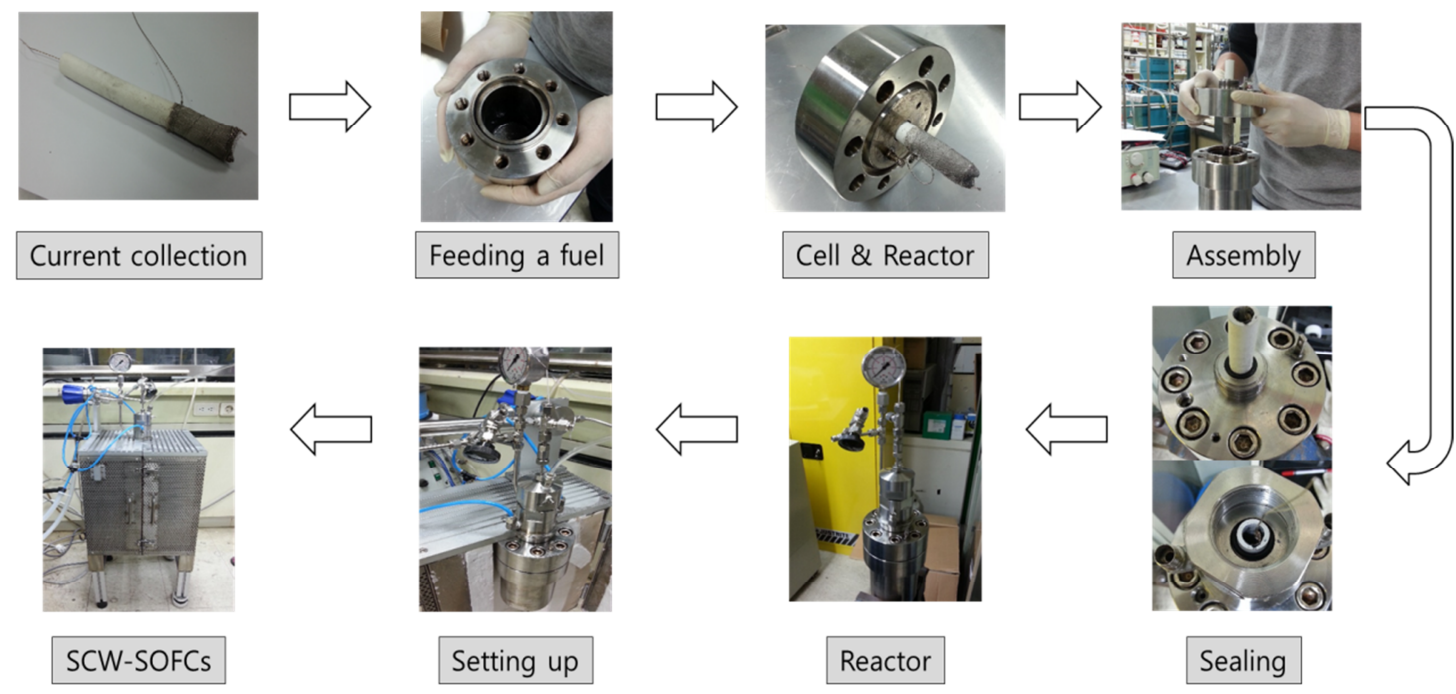

Figure 5. Assembly process of the SCW-SOFCs system.

Figure 6 shows the OCV behavior of the SCW-SOFC with $10 \mathrm{wt} . \%$ pectin in water. During heating up, the pressure gradually increased up to $22 \mathrm{MPa}$ at $400^{\circ} \mathrm{C}$. As clearly shown above, the maximum OCV realized was $0.29 \mathrm{~V}$, which means pectin was partially reformed and the product gas of $\mathrm{H}_{2}$ was used as the fuel. When pectin is fully reformed, it is converted to $\mathrm{CO}$ and $\mathrm{H}_{2}$ in a ratio of about 6:5, and the OCV ranges between 0.8 and $1.1 \mathrm{~V}(10)$. However, when the OCV reached $0.29 \mathrm{~V}$, the OCV dropped because the cell could no longer withstand the high pressure.

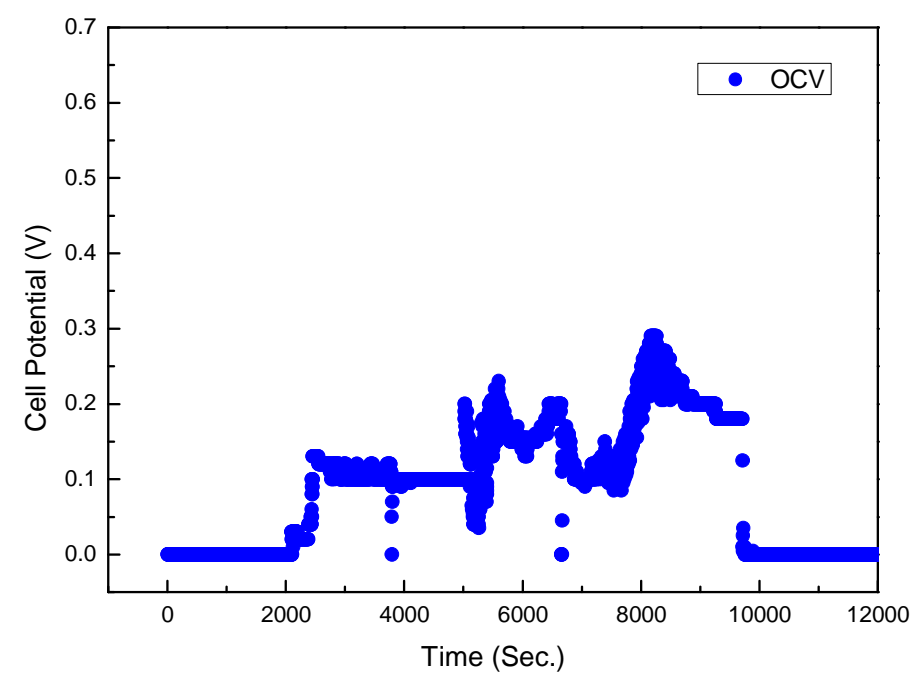

Figure 6. Open circuit voltage at $22 \mathrm{MPa}$ and $400^{\circ} \mathrm{C}$.

Figure 7 shows the OCV behavior of the SCW-SOFC with $5 \mathrm{wt} . \%$ pectin in water. The pressure was slowly increased up to $50 \mathrm{MPa}$ at $400^{\circ} \mathrm{C}$. A maximum $\mathrm{OCV}$ of $0.6 \mathrm{~V}$ 
was observed; the OCV was more stable than using fuel with $10 \mathrm{wt} . \%$ pectin in water because of well dissolved oxidant. However, the OCV also decreased dramatically, because it could not withstand the high pressure. An electrochemical study (i.e. i-V measurement and AC impedance analysis) has not been carried out yet. However, since the OCV value was high, it is expected that optimization of the cell microstructure and assembly of the SCW-SOFCs will lead to further electrochemical improvement. This is presently being investigated.

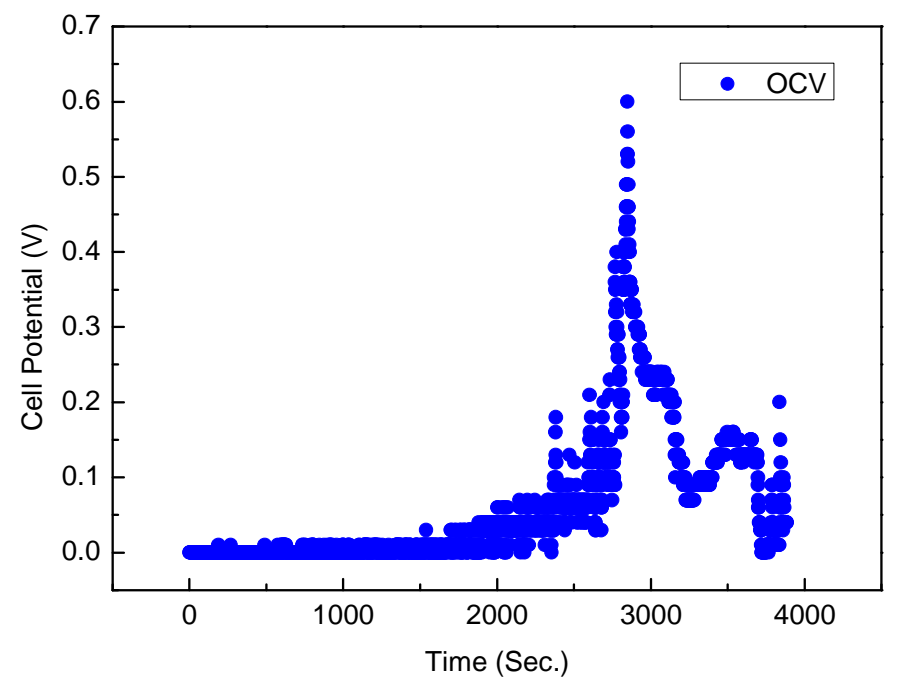

Figure 7. Open circuit voltage at $50 \mathrm{MPa}$ and $400^{\circ} \mathrm{C}$.

\section{Conclusion}

In this paper, a SCW-SOFC electrolyte-supported tubular cell was fabricated via piston extrusion of $8 \mathrm{~mol} \%$ YSZ electrolyte support, onto which Ni-YSZ cermet anode functional layer and LSCF cathode were coated. The SCW reactor consisted of a batch reactor with a heating system, where the SOFC cell is placed inside the reactor with the anode on the outside of the tube, and air passing through the center. The cell was electrochemically evaluated in supercritical water with 5 and $10 \mathrm{wt}$. \% of pectin. A maximum OCV of $0.6 \mathrm{~V}$ was observed. This shows the possibility that SOFCs can produce electricity under supercritical condition with water/fuel and oxygen.

\section{Acknowledgments}

This study was funded by a grant from the Bill and Melinda Gates Foundation.

\section{References}

1. G. A. Tompsett, C. Finnerty, K. Kendall, T. Alston and N. M. Sammes, J. Power Sources, 86, 376 (2000).

2. N. M. Sammes and R. Boersma, J. Power Sources, 86, 98 (2000).

3. R. J. Gorte and J. M. Vohs, J. Catal., 216, 477 (2003).

4. N. M. Sammes, Y. Du and R. Bove, J. Power Sources, 145, 428 (2000). 
5. H. Ohtaki, J. Molecular Liquids, 103, 3 (2000).

6. Ph. Wemet, D. Testemale, J.-L. Hazemann, R. Argoud and P. Glatzel, J. Chem. Phys., 123,154503 (2005).

7. N. Srisiriwat and A. Srisiriwat, Thammasat Int. J. Sc. Tech., 15, 47 (2010).

8. H. Kim, W. J. Kim, J. W. Lee, S. B. Lee, T. H. Lim, S. J. Park, R. H. Song and D. R. Shin, Korean Chem. Eng. Res., 50, 749 (2012).

9. S. C Singhal and K. Kendall, High Temperature Solid Oxide Fuel Cells: Fundamentals, Design and Applications, p. 83, Elsevier Ltd, Oxford (2003).

10. M. Homel, T. M. Gür, J. H. Koh, A. V. Virkar, J. Power Sources, 195, 6367 (2010). 